\title{
THE INFLUENCE \\ OF ORGANIZATIONAL VALUES \\ ON COMPETENCIES OF MANAGERS
}

\author{
Mitja Gorenak, Marko Ferjan
}

\section{Introduction}

Understanding the meaning of organizational values and their influence on employee performance is becoming more and more important. Several psychologists [51], [53], [30], have been researching values for decades, both at individual and at organizational level. There is also a view [35] of organizational values that argues that just as any human community has its own value system the same is true for any organization. Taking that into account, we are facing a dilemma, whether [16] organizational values are something that emerges from an organization or are they simply transferred from an individual level to the organizational level by its employees. It is very likely that organizational values develop through a mixture [16] of both. Thus, at the beginning organizational values resemble personal values of the founder or founders of an organization. However, as the organization grows, its values alter in that they incorporate new experiences that bring about new values, thus making an entirely new set of organizational values that are specific to that very organization.

Organizational values are a part of organizational culture [52] and represent [51] relatively permanent, motivational, emotionally positive categories, for which people believe that they are worth aspiring to (love, peace, friendship, health, etc.). Through values we can also see (lifetime) goals, which reflect cultural or spiritual development of an individual or an organization. Boyatzis is regarded as one of the founders of modern definitions of competencies and argues that [9] values are the basis of the definition of competencies. There are many other definitions of competencies [45], [56], [13], [23], [46], [7] in which the following is emphasized: personal characteristics, knowledge, abilities, motivation, self-image and values. Above-mentioned authors agree that competencies develop through time based on experiences people get by performing various jobs.

The concept of correlation of organizational values with competencies is based upon a correlation that is already established within organizational culture, for which we know that organizational values are a part of. It attracts people with similar values, beliefs, knowledge, skills and abilities. In other words, certain competencies have an indirect influence on the development of organizational culture. The motivation for this research evolved form discussion [39] in which tried to answer the question of how to link and explore organizational values with managers' competencies. It was suggested [39] that the best way to link and explore this is at the process level where we can compare processes within an organization and involvement as well as cooperation of managers within those same processes. This kind of research has some limitations, such as a limited number of processes that can be investigated, which is why we have decided to conduct a cross-sectional research, as it enables us to investigate a much bigger sample.

\section{Theoretical Background}

\subsection{Values}

Values are beliefs upon which individuals perform their tasks [3] on the basis of their preferences. On the other hand, values are relatively permanent [21] perceptional frames that shape and influence the nature of individuals' behavior. Much work in the area of values was also done by Rokeach [50] who defined values as "types of beliefs, that are centrally located in individuals system of beliefs and they represent individual's attitudes towards how someone should or should not behave." Extensive research on values [54] 
has made a definition of values from the socialpsychological perspective saying that "values are:

- beliefs or conceptualizations,

- about wanted end states or behaviors,

- that exceed specific situations,

- direct the evaluation of behavior, and

- rated regarding the relative importance."

With this definition we have, to some extent, moved away from, at that point, well-established model proposed before [51].

\subsection{Organizational Values}

When discussing the problem of defining organizational values it was [48] concluded that organizational values evolve from organizational culture; they believe that this is generally the philosophy which an organization follows. Organizational values [55] are written within organizational culture, given that organizational culture defines expectations regarding behavior, modes of conduct, modes of decision-making and communication styles. Further it is stressed that the importance of a broader discussion regarding organizational values is important since this is the only way towards an agreement on the definition of values.

Various authors [47], [16], [14] have been discussing the correlation between organizational values and long-term performance of organizations, this correlation is proven on several practice cases. It has also been determined that organizations with clearly stated organizational values, which are internalized by employees, reach significantly higher performance results compared to values which are less clearly stated or not stated at all [16]. On the other hand there have been warnings about potential hazards young organizations are faced with, especially regarding organizational values [20], that when an organization is young and growing miss defined organizational values can hinder its growth and potentially endanger its development.

\subsection{Fit of Values}

When discussing how organizational values fit personal values, we can identify four prominent theories that were developed through time.

In the field of interactional theory, [40] we can see proposition of a fit between personal values and environmental values (personalityenvironment fit theory). For the purpose of this article we will focus on two theories: a theory that focused on fit between a person and a job (personality-job fit theory) [31], and theory [34] which focused on a fit between a person and an organization (personality-organizational fit). The remaining two theories are theory [32] of fit between a person and one's vocation (personal-vocational fit) and a theory [29], [26] which discusses the fit between a person and a group (personality-group fit). Research [49] also found out that the higher level of fit between organizational and personal values is clearly shown in individuals' positive approach to work as employees are more satisfied when they are performing their tasks.

\subsection{Competencies}

Boyatzis considered by many to be a pioneer in the field of competencies, has done an extensive research among managers in the USA, identifying factors that influence their success [9]. The study focused on managerial competencies. Findings [9] revealed that competencies are a mixture of individuals' motives, abilities, self-image, social role and knowledge that a person uses in social interactions. On the other hand, we can see definition of competencies [42] in a differently as knowledge, that one had gained. As such they are influenced by motives, abilities, self-image, social role and knowledge that one uses in social interactions [9]. There are other authors [4], [8] who view competencies as individuals' behaviors in a certain situation. In this respect, they understand knowledge as something that is individually learned; they propose behaviors to be the reflection of competencies. Yet another definition of competencies was proposed [37] that somewhat incorporates various other definitions of competencies, by saying that he understands individuals competencies as: "activation, implementation and cohesion of all the knowledge's, abilities, motives, self image and values that enables the individual to perform tasks and solve problems in complex, various and unexpected situations that face him".

Moreover, another interesting definition was proposed [46] that "competencies are appliance and correlation of knowledge, abilities, motives, self image and values that shape individuals competencies". Some have identified competencies as [28], [7] personal characteristics that have evolved through the educational process and were further shaped by work in organization; therefore, authors do not just take into account the 
educational process but also the work experience; however, we can also see addition of the social environment [41], [10], in the so called primary socialization period.

\subsection{The Influence between Organizational Values and Competencies of Managers}

The concept of linking organizational values to competencies was linked with organizational culture, as organizational values are a part of it and as such they attract people with similar value principles and knowledge, skills and abilities. In other words, certain competencies influence how organizational culture is created. Therefore, this indicates that there is a correlation between organizational values and competencies that is worth researching. This, however, does not mean that this area has not yet been researched. For example, the process examined level where we can compare processes within an organization and involvement as well as managers' cooperation within those same processes [39]. Although this research yielded some results, we believe that the very decision to research the process level has influenced the results, showing less correlation than there actually is. We can also see investigation of the correlation between managers' values and organizational culture [5]; findings which refer to managers' values are still relevant today and have influenced the development of organizational culture. The studies discussed above are in line with our initial assumption that there is a correlation between organizational values and managers' competencies, thus making this topic particularly interesting to research.

\section{Research Model}

Having closely studied various scientific and professional literature (studies and theories on organizational values and competencies) we have determined that there is no model that could be applied to our data. This encouraged us to develop and propose our own model, though we knew that this also brings about some limitations:

- First, we decided to analyze organizational values of numerous organizations; we noted how many times a certain organizational value shows up and concluded that the following six organizational values most frequently occur in organizations from the travel and leisure industry: quality, innovation, responsibility, ethics, customers and employees.

- Second, each organizational value was matched up with a competency that is in line with the meaning of that value. Based on this, six organizational values and matching competencies were identified. Furthermore, indicators were identified that represent each organizational value or competence that was tested before. We adapted those indicators to our model, shown in Figure 1.

\section{Fig. 1: Research model}

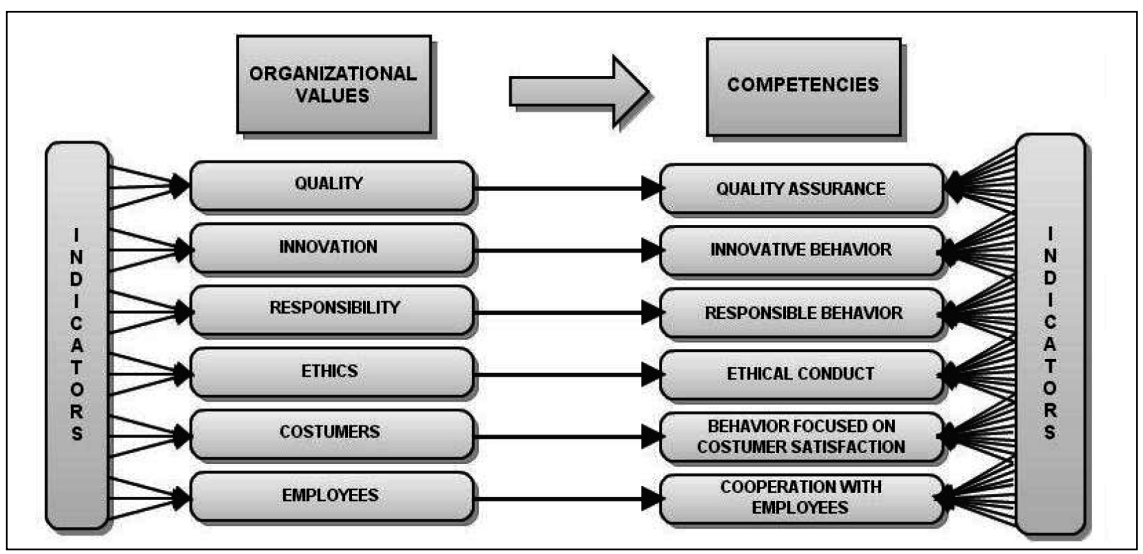


The left column of the model features indicators that have been previously formed [44]. Quality thus refers to the quality of work and life, whereas innovation refers to quest for quality and facilitation of quality. The value responsibility refers to responsible use of resources and responsible behavior. Similarly, the value ethics refers to ethical behavior and ethical standards. The value customers refer to knowledge that costumers are the focal point of every organization. Last but not least, the value employees refer to knowledge that employees are a powerful source of the company.

The right hand side presents competencies with indicators. They were adapted from the competency profile published by the Center of Republic of Slovenia for Vocational Training (here on CVT). For the purpose of this research a competency model developed by CVT for the profession of hotel managers was used [15]. This standard includes 114 work tasks and for each competence that we have in our model we selected 8 tasks, which reflect a certain competency.

Indicators for values have already been tested [44]. However, the indicators for competencies still needed to be tested. For this reason a pilot research was conducted that confirmed the validity of selected indicators. Nevertheless, minor changes were undertaken before the survey, presented in this study, was conducted.

\section{Methodology}

\subsection{Research Question and Hypothesis}

The aim of the research was to test the validity of the model shown in Figure 1. To this end, our research question is: Is there a statistically significant influence of organizational values on matching competencies?

In order to answer this research question the following research hypothesis was set up:

$\mathrm{H}$ : The organizational values statistically significantly influence competencies of managers.

\subsection{Instrument}

The correlation was tested using a questionnaire with a paper-and-pencil survey. The whole population of the sector (travel and leisure) represents 9,117 people. We have been given consent from several organizations within the sector that employs 2,762 people. 1,100 questionnaires were distributed. The sampling within organizations was random. Of 1100 questionnaires, 388 were returned, what represents $35.27 \%$ of all questionnaires sent out, i.e. $4.26 \%$ of the entire population.

The questionnaire comprised 75 questions relating to (1) organizational values, (2) competencies and (3) respondent's details (age, gender, number of working years, level of education etc.).

\subsection{Sample}

We evaluated the validity of the sample within the selected sector. The test chi-square test of significance was employed on the following demographic information of respondents: gender, education and age. For the variable sex, chi-square was 0.598 and significance level at $p=0.434$, for the variable education, the chi-square test was 9.296 with significance level at $p=0.054$, the final variable age provided a value of 13.971 , and the level of significance was at $p=0.052$.

The value of chi-square distribution at significance 0.05 or $5 \%$ are for variables with single degree of freedom (variable gender) 3.8415 , for variables with four degrees of freedom (variable education) 9.4877 and for variables with seven degrees of freedom (variable age) 14.0671 [38].

Based on the findings we can conclude that the research sample could be generalized to the whole population.

The sample which has been used for the purpose of this paper contained $133(38.4 \%)$ male respondents and $213(61.6 \%)$ female respondents. The data on age groups are presented in Table 1.

The data on education are shown in Table 2. 
Tab. 1: Age groups of respondents'

\begin{tabular}{c|c|c} 
Age group & Responses & $\%$ \\
\hline Up to 24 years (inclusive) & 31 & 8.9 \\
\hline from 25 to 29 years & 49 & 14.0 \\
\hline from 30 to 34 years & 53 & 15.2 \\
\hline from 35 t0 39 years & 51 & 14.6 \\
\hline from 40 to 44 years & 60 & 17.2 \\
\hline from 45 to 49 years & 50 & 14.3 \\
\hline from 50 to 54 years & 38 & 10.9 \\
\hline 55 years or more & 17 & 4.9 \\
\hline Total & 349 & 100.0 \\
\hline
\end{tabular}

Source: [24]

\begin{tabular}{l|c|c} 
Tab. 2: & \multicolumn{1}{c}{ Education of respondents } \\
Education & Responses & $\%$ \\
\hline Elementary school or less & 34 & 9.6 \\
\hline Vocational high school & 83 & 23.5 \\
\hline High school & 121 & 34.3 \\
\hline College degree & 80 & 22.7 \\
\hline University degree or more & 35 & 9.9 \\
\hline \multicolumn{1}{c|}{ Total } & 353 & 100.0 \\
\hline
\end{tabular}

\section{Results}

First, we tested the validity of the questionnaire using the Cronbach's alpha test, calculating the coefficients for each set of variables. We have performed this test on variables that measured values first; the value was 0.859 , thus indicating great reliability of measurement. For variables that measured competency quality the value was 0.833 , for variables measuring innovation competence the value was 0.823 , for variables measuring responsibility competence the value was 0.855 . Moreover, for variables that measured the ethics competence the value was 0.841 and for customers competence the value was 0.840 . Finally, the variables that measured the quality competence the value was 0.861 . These values indicate great reliability of measurement [22] and with regard to the composition and characteristics of the sample, we believe that it is representative.

\subsection{Formatting Merged Variables}

The structure of the questionnaire used in the survey demanded some variables to be merged and not used individually. Values of some variables that were intentionally formed in negative form statements were transformed through the statements before creating composite variables and were not changed into positive form.

In the first step we have conducted a factor analysis on the set of first 20 variables that measured organizational values. Out of 20 variables 12 of them have positioned themselves in 6 different factors with suitable weights, other 8 have either not positioned in any of the factors or have had minimum weight in two or more factors that is why we have removed them. Results are shown in Table 3. 
Tab. 3: Factor analysis of variables that measured organizational values

\begin{tabular}{|c|c|c|c|c|c|c|}
\hline \multirow{2}{*}{ Variable } & \multicolumn{6}{|c|}{ Factor } \\
\hline & 1 & 2 & 3 & 4 & 5 & 6 \\
\hline V3 Quality of work is important in our organization. & .942 & & & & & \\
\hline $\begin{array}{l}\text { V4 Within our organization we are focused } \\
\text { on successfully completing our tasks. }\end{array}$ & .754 & & & & & \\
\hline $\begin{array}{l}\text { V20 Encouragement of positive examples is rare } \\
\text { in our organization. }\end{array}$ & & .726 & & & & \\
\hline $\begin{array}{l}\text { V15 Inhibition of innovative ideas is frequent } \\
\text { in our organization. }\end{array}$ & & .710 & & & & \\
\hline $\begin{array}{l}\text { V18 Adaptation to different business situations } \\
\text { presents a problem for our organization. }\end{array}$ & & & .659 & & & \\
\hline $\begin{array}{l}\text { V10 Immoral behavior at work is acceptable } \\
\text { in our organization. }\end{array}$ & & & .620 & & & \\
\hline V7 In our organization we respect each other. & & & & .902 & & \\
\hline V12 Employees in our organization interact. & & & & .622 & & \\
\hline $\begin{array}{l}\text { V19 In our organization we try to satisfy the needs } \\
\text { of our costumers. }\end{array}$ & & & & & .869 & \\
\hline $\begin{array}{l}\text { V8 Practices in our organization are focused } \\
\text { on our costumers/guests. }\end{array}$ & & & & & -.533 & \\
\hline $\begin{array}{l}\text { V5 At work in our organization we behave responsibly } \\
\text { towards others around us. }\end{array}$ & & & & & & .723 \\
\hline $\begin{array}{l}\text { V2 To achieve the objectives within our organization } \\
\text { we are working persistently. }\end{array}$ & & & & & & .210 \\
\hline
\end{tabular}

We have named the factors that we have determinated in Table 3 in the following order; the first factor represents quality, so we have merged the variables in the first factor into new variable named OVQ - Organizational value quality. The variables in the second factor represent innovativeness, so we have merged the variables in the second factor in new variable named $\mathbf{O V I}$ - Organizational value innovation. The variables in the third factor represent ethical conduct, so we have merged the variables in the third factor in new variable named OVE Organizational value ethics. The variables in the fourth factor represent employees, so we have merged the variables in the fourth factor in new variable named OVE - Organizational value employees. The variables in the fifth factor represent costumers, so we have merged the variables in the fifth factor in new variable named OVC - Organizational value costumers. The variables in the final sixth factor represent responsibility, so we have merged the variables in the sixth factor in new variable named OVR Organizational value responsibility.

Some may argue that the second variable in sixth factor V2 To achieve the objectives within our organization we are working persistently is not suitable to be positioned due to the relatively low weight that it has, but due to the fact that it has positioned only in this sixth factor and it has positioned as a second not a leading variable in this factor we have decided to use it anyways. With the help of factor analysis we were able to explain $67.76 \%$ of variability of organizational values with these 12 variables in 6 factors.

In the second step we have conducted a factor analysis on the set of second 48 variables that measured competencies. Out of 48 variables 30 of them have positioned themselves in 6 different factors with suitable weights, other 18 have either not positioned in any of the factors or have had minimum weight in two or more factors that is why we have removed them. Results are shown in Table 4. 
Tab. 4: Factor analysis of variables that measured competencies (part 1)

\begin{tabular}{|c|c|c|c|c|c|c|}
\hline \multirow{2}{*}{ Variable } & \multicolumn{6}{|c|}{ Factor } \\
\hline & 1 & 2 & 3 & 4 & 5 & 6 \\
\hline $\begin{array}{l}\text { U1 My manager communicates with costumers } \\
\text { respectfully. }\end{array}$ & .719 & & & & & \\
\hline $\begin{array}{l}\text { E5 My manager supervises compliance of external } \\
\text { and internal regulations. }\end{array}$ & .544 & & & & & \\
\hline $\begin{array}{l}\text { O6 My manager monitors the results } \\
\text { of the organizational unit. }\end{array}$ & .516 & & & & & \\
\hline $\begin{array}{l}\text { E4 My manager works in accordance with } \\
\text { the environmental protection measures. }\end{array}$ & .509 & & & & & \\
\hline $\begin{array}{l}\text { O2 My manager distributes the work of subordinates } \\
\text { according to workload. }\end{array}$ & .487 & & & & & \\
\hline $\begin{array}{l}\text { U3 My manager takes care of the importance } \\
\text { of contacts with costumers. }\end{array}$ & .481 & & & & & \\
\hline $\begin{array}{l}\text { O7 My manager takes care to ensure the rational } \\
\text { use of energy, materials and time. }\end{array}$ & .455 & & & & & \\
\hline $\begin{array}{l}\text { E6 Disrespectful communication with employees } \\
\text { is typical for my manager. }\end{array}$ & & .696 & & & & \\
\hline E3 Immoral conduct is typical for my manager. & & .581 & & & & \\
\hline $\begin{array}{l}\text { Z1 My manager's conduct creates a negative } \\
\text { atmosphere. }\end{array}$ & & .580 & & & & \\
\hline $\begin{array}{l}\text { U8 My manager fails to ensure good relationships } \\
\text { with customers. }\end{array}$ & & .538 & & & & \\
\hline $\begin{array}{l}\text { E7 My manager has a discriminatory attitude towards } \\
\text { employees. }\end{array}$ & & .494 & & & & \\
\hline $\begin{array}{l}\text { I2 Encouraging changes to the procedures at work are } \\
\text { typical for my manager. }\end{array}$ & & & .652 & & & \\
\hline $\begin{array}{l}\text { K3 My manager is monitoring the implementation } \\
\text { of tasks. }\end{array}$ & & & .495 & & & \\
\hline $\begin{array}{l}\text { K2 My manager resolves demanding complaints } \\
\text { professionally. }\end{array}$ & & & .474 & & & \\
\hline $\begin{array}{l}\text { K4 My manager encourages employees to perform } \\
\text { better at work. }\end{array}$ & & & .465 & & & \\
\hline $\begin{array}{l}\text { I5 Timely identification of new forms of work is typical } \\
\text { of my manager. }\end{array}$ & & & .443 & & & \\
\hline K1 My manager does not supervise the work process. & & & & .771 & & \\
\hline $\begin{array}{l}\text { K5 My manager does not control the quality } \\
\text { of performed work. }\end{array}$ & & & & .566 & & \\
\hline $\begin{array}{l}\text { O1 My manager irresponsibly orders the work } \\
\text { of employees. }\end{array}$ & & & & .506 & & \\
\hline $\begin{array}{l}\text { K8 My manager is not able to deal with tasks } \\
\text { in timely manner. }\end{array}$ & & & & .467 & & \\
\hline $\begin{array}{l}\text { O3 My manager is unprofessional at organization } \\
\text { of work within the unit. }\end{array}$ & & & & .456 & & \\
\hline
\end{tabular}

of work within the unit. 


\section{Tab. 4: Factor analysis of variables that measured competencies (part 2)}

\begin{tabular}{l|l|l|l|l|l|l}
\multicolumn{1}{c|}{ Variable } & \multicolumn{5}{c}{ Factor } \\
\cline { 2 - 6 } & $\mathbf{1}$ & $\mathbf{2}$ & $\mathbf{3}$ & $\mathbf{4}$ & $\mathbf{5}$ & $\mathbf{6}$ \\
\hline $\begin{array}{l}\text { Z7 Providing instruction to new employees at work } \\
\text { is typical for my manager. }\end{array}$ & & & & & .802 & \\
\hline $\begin{array}{l}\text { Z2 My manager participates as a mentor to new } \\
\text { employees. }\end{array}$ & & & & & .702 & \\
\hline Z8 My manager advises employees at work. & & & & & .653 & \\
\hline $\begin{array}{l}\text { Z4 Caring for the continuous development of employe- } \\
\text { es is typical of my manager. }\end{array}$ & & & & & .539 & \\
\hline $\begin{array}{l}\text { Z3 Resolving the concrete problems in the process is } \\
\text { the nature of my manager. }\end{array}$ & & & & & .466 & \\
\hline $\begin{array}{l}\text { U6 My manager prepares special market outlets } \\
\text { (discounts, credits, ect.) }\end{array}$ & & & & & & .465 \\
\hline U7 My manager monitors customer loyalty. & & & & & & .374 \\
\hline U5 My manager monitors supply on the market. & & & & & & .351 \\
\hline
\end{tabular}

We have named the factors that we have determinated in Table 4 in the following order; the first factor represents responsible behavior, so we have merged the variables in the first factor into new variable named CR - Competencies responsibility. The variables in the second factor represent ethical conduct, so we have merged the variables in the second factor in new variable named $\mathbf{C E}$ - Competencies ethics. The variables in the third factor represent innovative behavior, so we have merged the variables in the third factor in new variable named $\mathbf{C l}$ - Competencies innovation. The variables in the fourth factor represent assurance of quality, so we have merged the variables in the fourth factor in new variable named $\mathbf{C Q}$ - Competencies quality. The variables in the fifth factor represent cooperation with employees, so we have merged the variables in the fifth factor in new variable named CEm - Competencies employees. The variables in the final sixth factor represent costumers, so we have merged the variables in the sixth factor in new variable named $\mathbf{C C}$ - Competencies costumers.

With the help of factor analysis we were able to explain $54.96 \%$ of variability of competencies with these 30 variables in 6 factors.
After forming new merged variables we have also merged all organizational values into one new variable that we have named OVMe - Organizational values merged. We did the same with all merged competencies and created another new variable named CMe Competencies merged. Our next step was to measure mean values and standard deviations in these newly formed variables, results are show in Table 5.

Illustrated in Table 5, neither of mean values nor standard deviations of newly formed variables are above the generally expected range. As far as mean values go there is not much of a difference between variables related to organizational values compared to the variables related to competencies, but when we look into the values of standard deviations we can see that the average standard deviation is slightly lower for variables related to competencies as opposed to variables related to organizational values.

Further interest was related to measuring the correlation between merged variables of organizational values and matching pairs of merged variables of competencies. Therefore Pearson's correlation coefficient was used; results are shown in Table 6. 
Tab. 5: Mean values and standard deviations of merged variables

\begin{tabular}{|c|c|c|}
\hline Merged variable & Mean value & $\begin{array}{l}\text { Standard } \\
\text { deviation }\end{array}$ \\
\hline \multicolumn{3}{|c|}{ Organizational values } \\
\hline OVQ - Organizational value quality & 4.32 & 0.90 \\
\hline $\mathrm{OVI}$ - Organizational value innovation & 3.40 & 1.06 \\
\hline OVR - Organizational value responsibility & 4.10 & 0.89 \\
\hline OVE - Organizational value ethics & 3.52 & 1.05 \\
\hline OVC - Organizational value customers & 4.07 & 0.80 \\
\hline OVEm - Organizational value employees & 3.64 & 0.93 \\
\hline OVMe - Organizational values merged & 3.83 & 0.63 \\
\hline \multicolumn{3}{|c|}{ Competencies } \\
\hline $\mathrm{CQ}$ - Competencies quality & 3.98 & 0.87 \\
\hline $\mathrm{Cl}$ - Competencies innovation & 3.68 & 0.86 \\
\hline CR - Competencies responsibility & 3.91 & 0.82 \\
\hline CE - Competencies ethics & 3.94 & 0.92 \\
\hline CC - Competencies customers & 3.76 & 0.91 \\
\hline CEm - Competencies employees & 3.67 & 0.91 \\
\hline $\mathrm{CMe}$ - Competencies merged & 3.84 & 0.69 \\
\hline
\end{tabular}

Among data shown in Table 6 we have highlighted the correlations that we are interested in. All the highlighted correlations are positive, the strength of the correlation is moderate in most cases [1], only the correlations between the organizational value responsibility and the competence responsibility and correlation between the organizational value costumers and the competence costumers are strong [1] in the matching pairs that we are interested in.

Also seen from Table 6 there are some other correlations that need to be mentioned. There is a strong correlation between organizational value costumers and competencies responsibility $\left(.628^{\star *}\right)$ what can be explained that in the sector that this research was conducted costumers are very important and therefore responsible behavior of managers towards costumers is completely expected. However, there are also some pairs that have not presented statistically significant correlation, among organizational values ethics and competencies responsibility there is no statistically significant correlation (.073) and this is somewhat alarming, since it tells us that organizational value ethics does not correlate with responsible behavior of managers.

In the following section we have conducted a linear regression analysis where the influence of between independent variables towards dependent variables was analyzed. The influence of each of the independent variables was evaluated so that it is not dependent on influences between various independent variables. Table 7 presents the values of regression among pairs of independent variables (organizational values) and matching pairs of dependent variables (competencies), as proposed in our research model. 


\section{Tab. 6: Correlation between individual merged variables}

\begin{tabular}{|c|c|c|c|c|c|c|}
\hline & 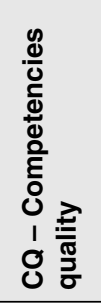 & 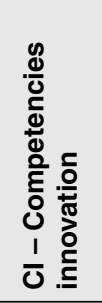 & 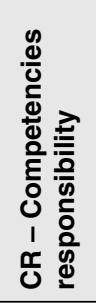 & 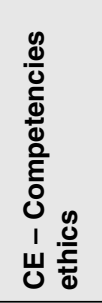 & 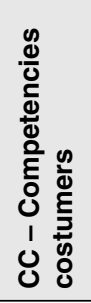 & 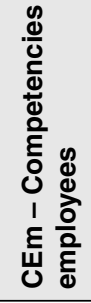 \\
\hline OVQ - Organizational value quality & $.277^{\star \star}$ & $.572^{\star *}$ & $.621^{* *}$ & $.242^{* *}$ & $.504^{\star *}$ & $.533^{\star *}$ \\
\hline OVI - Organizational value innovation & $.366^{\star *}$ & $.203^{\star \star}$ & $.109^{*}$ & $.427^{\star \star}$ & $.157^{\star *}$ & $.141^{\star *}$ \\
\hline OVR - Organizational value responsibility & $.281^{* *}$ & $.503^{\star *}$ & $.534^{\star \star}$ & $.244^{\star *}$ & $.476^{\star *}$ & $.596^{\star *}$ \\
\hline OVE - Organizational value ethics & $.379^{\star *}$ & $.133^{*}$ & .073 & $.397^{\star \star}$ & $.140^{* *}$ & .086 \\
\hline OVC - Organizational value customers & $.254^{\star *}$ & $.587^{\star *}$ & $.628^{* *}$ & $.224^{\star *}$ & $.523^{\star *}$ & $.543^{\star *}$ \\
\hline OVEm - Organizational value employees & $.294^{\star \star}$ & $.485^{\star \star}$ & $.492^{* *}$ & $.293^{* *}$ & $.448^{* *}$ & $.497^{\star *}$ \\
\hline
\end{tabular}

${ }^{* *}$ Correlation is significant at the 0.01 level (2-tailed).

Tab. 7: Regression analysis between organizational variables and competencies

\begin{tabular}{l|c|c|c}
\multicolumn{1}{c|}{$\begin{array}{c}\text { Regression } \rightarrow \text { Organizational } \\
\text { values - competencies }\end{array}$} & $\Delta \mathbf{R}^{2}$ & $\mathbf{F}$ & $\mathbf{P}$ \\
\hline $\begin{array}{l}\text { OVQ - Organizational value quality - } \\
\mathrm{CQ} \text { - Competencies quality }\end{array}$ & .074 & 30.761 & .000 \\
\hline $\begin{array}{l}\text { OVI - Organizational value innovation - } \\
\mathrm{Cl} \text { - Competencies innovation }\end{array}$ & .038 & 15.784 & .000 \\
\hline $\begin{array}{l}\text { OVR - Organizational value responsibility - } \\
\text { CR - Competencies responsibility }\end{array}$ & .283 & 143.634 & .000 \\
\hline $\begin{array}{l}\text { OVE - Organizational value ethics - } \\
\text { CE - Competencies ethics }\end{array}$ & .155 & 67.832 & .000 \\
\hline $\begin{array}{l}\text { OVC - Organizational value customers - } \\
\text { CC - Competencies customers }\end{array}$ & .272 & 115.495 & .000 \\
\hline $\begin{array}{l}\text { OVEm - Organizational value employees - } \\
\text { CEm - Competencies employees }\end{array}$ & .245 & 119.724 & .000 \\
\hline $\begin{array}{l}\text { OVMe - Organizational values merged - } \\
\text { CMe - Competencies merged }\end{array}$ & .397 & 179.457 & .000 \\
\hline
\end{tabular}

Table 7 shows the results of linear regression. The first pair includes the independent variable OVQ - Organizational value quality and the dependent variable $C Q$ - Competencies quality. Result $\left(\Delta R^{2}=0.074 ; F=30.761 ; p=0.000\right)$ shows that with the influence of OVQ - Organizational value quality we can explain $7.4 \%$ of variability of value for $C Q$ - Competencies quality. In the second pair, we put the independent variable OVI - Organizational value innovation, and dependent variable $\mathrm{Cl}$ - Competencies innovation. Result $\left(\Delta \mathrm{R}^{2}=0.038 ; \mathrm{F}=15.784\right.$; $\mathrm{p}=0.000$ ) shows that with the influence of OVI - Organizational value innovation we can explain $3.8 \%$ of variability of value for $C Q-$ Competencies innovation, in the third pair we put 
the independent variable OVR - Organizational value responsibility and the dependent variable $C R-C o m p e t e n c i e s$ responsibility. The findings show $\left(\Delta R^{2}=0.283 ; F=143.634 ; p=0.000\right)$ that with the influence of OVR-Organizational value responsibility we can explain $28.3 \%$ of variability of value for $C R$ - Competencies responsibility, in the fourth pair we put the independent variable OVE - Organizational value ethics, and dependent variable $C E$ - Competencies ethics. Results $\left(\Delta R^{2}=0.155 ; F=67.832 ; p=0.000\right)$ show that with the influence of OVE - Organizational value ethics we can explain $15.5 \%$ of variability of value for $C E$ - Competencies ethics, in the fifth pair we put the independent variable OVC Organizational value costumers, and dependent variable $C C$-Competencies costumers. Results $\left(\Delta R^{2}=0.272 ; F=115.495 ; p=0.000\right)$ show that with the influence of OVC - Organizational value costumers we can explain $27.2 \%$ of variability of value for CC - Competencies costumers, in the final sixth pair we put the independent variable OVEm - Organizational value employees, and the dependent variable CEm - Competencies employees. Results $\left(\Delta \mathrm{R}^{2}=0.245 ; \mathrm{F}=119.724\right.$; $\mathrm{p}=0.000$ ) show that with the influence of OVEm - Organizational value employees we can explain $24.5 \%$ of variability of value for CEm Competencies employees.

We also performed this same linear regression analysis on the independent variable OVMe Organizational value merged, and dependent variable $\mathrm{CMe}-$ Competencies merged. Results $\left(\Delta \mathrm{R}^{2}=0.397 ; \mathrm{F}=179.457 ; \mathrm{p}=0.000\right)$ show that with the influence of OVMe-Organizational value merged, we can explain $39.7 \%$ of variability of value for $\mathrm{CMe}$-Competencies merged.

Based on the results we can confirm the hypothesis $\mathrm{H}$ : The organizational values influence competencies of managers.

\section{Practical Implications of Findings}

Our results can be backed up by several other findings. As presented, respondents who more often said that organizational value quality is important for an organization in which they work also more often said that quality competencies more often show the way their managers work $(r=0.277$ Correlation is significant at the 0.01 level (2-tailed)), adding to that the results of linear regression, in the this first pair we see that the independent variable OVQ - Organizational value quality explains $7,4 \%$ of variability of the dependent variable $C Q-$ Competencies quality.
This backs up the findings [11] that managers support organizational values related to quality, that are supported in ongoing behavior of managers and will have impact on quality of performance.

We have also showed that respondents who more often said that organizational value innovation is important for organization in which they work also more often say that innovative competencies also more often show the way their managers work $(r=0.203$ Correlation is significant at the 0.01 level (2-tailed), adding to that the results of linear regression, in the this second pair we see that the independent variable $\mathrm{OVI}$ - Organizational value innovation, explains $3.8 \%$ of variability of the dependent variable $\mathrm{Cl}$ - Competencies innovation. Since the result is the lowest among all six pairs this corresponds with findings that found out that [12] innovation among service and tourism enterprises is characterized by relatively low propensity for the development of new products and processes.

For those respondents who more often said that the organizational value responsibility is important for the organization in which they work also more often said that responsibility competencies also more often show the way their managers work $(r=0.534$ Correlation is significant at the 0.01 level (2-tailed). Adding the results of linear regression for the third pair we see that the independent variable OVR Organizational value responsibility, explains $28.3 \%$ of variability of the dependent variable $C R$ - Competencies responsibility. This also backs up research [36] which showed that in organizations where responsibility is shown as organizational value, managers take it as their own and make it one of their focal values.

Among those respondents that more often said that organizational value ethics is important for the organization in which they work also more often said that ethical competencies show the way their managers work ( $r=0.397$ Correlation is significant at the 0.01 level (2-tailed), adding to that the results of linear regression, in the fourth pair we see that the independent variable OVE - Organizational value ethics, explains $15.5 \%$ of variability of the dependent variable $C E-$ Competencies ethics. This finding corresponds with findings [33] that have proven that positive attitude of managers towards ethical organizational values is shown in individuals' performance and effects of 
organizational performance as well. However, this does not support the claim [2] that ethical values are amongst least important ones, since our values put it somewhere in the middle.

We have also given evidence that those respondents that more often said that organizational value costumers is important for organization in which they work also more often say that costumer oriented competencies also more often show the way their managers work ( $r=0.523$ Correlation is significant at the 0.01 level (2-tailed), adding to that the results of linear regression, in the this fifth pair we see that the independent variable OVC - Organizational value costumers, explains $27.2 \%$ of variability of the dependent variable $C C$ - Competencies costumers. This combined, backs up findings that [43] have concluded that if management supports the costumer-driven focus higher hotel performance levels are more likely to be the outcome.

In our research, those respondents, who more often expressed that organizational value employees is important for an organization in which they work, are also more often convinced that employee oriented competencies also more often show the way their managers work $(r=0.497$ Correlation is significant at the 0.01 level (2-tailed), adding to that the results of linear regression, in the this sixth pair we see that the independent variable OVEm - Organizational value employees, explains $24.5 \%$ of variability of the dependent variable CEm-Competencies employees. This backs up research [25] that determined that leaders (managers) who adopt organizational values are more likely to be followed by their employees.

The findings are relevant for everyday management within organization and this research directly supports the idea [17] of transforming management style from previously known Management by objectives (MBO) [19] to Management by Values (MBV). Although Management by values was previously discussed by others [6] it was the contribution made by Dolan and Garcia [17] and their further work Dolan et. al. [18], which evolved the theory to the extent that we know it today. The theory suggests that in the modern world managing by objectives is not good enough. It is no doubt that modern day employees want to be empowered, they want to have more responsibilities, more freedom with creativity, more flexibility and above all more autonomy in their decision.
This presents a problem for the management, especially in the part where management is responsible for overseeing employees' work, since it is hard to control employees and at the same time give them autonomy in their work.

\section{Conclusion}

Many authors have discussed the different meanings and influences individuals as well as organizational values may have on other phenomena, the same goes for competencies. Based on theoretical knowledge and the findings of previous research, a conceptual model of organizational values influence on competencies of managers was developed and tested. In principle we can assert that findings of other studies regarding the researched topics support the objectives, set in this paper. Hence, we may conclude that there is an undeniable influence of organizational values on managers' competencies. Taking this into account we can say that we have proven that theory of management by values [17] is valid.

For each of the six selected organizational values (quality, innovation, responsibility, ethics, customers and employees) we have shown that there is a direct correlation to the corresponding behavioral patterns that are represented in managers' competencies (quality assurance, innovative behavior, responsible behavior, ethical conduct, behavior focused on customer satisfaction and cooperation with employees). Using linear regression analysis we may confirm that each organizational value explains a certain percentage of corresponding competence of managers.

The statistically significant correlation $(r=0.277)$ as well as a relatively high level of variability $(7.4 \%)$ explained between independent variable OVQ - Organizational value quality and variable $C Q$ - Competencies quality, clearly shows that quality is very important for any organization, since nowadays more or less everything is about quality, and customers want better quality in every aspect. On the other hand, the statistically significant correlation $(r=0.203)$ as well as a relatively low level of variability (3.8\%) explained between the independent variable OVI - Organizational value innovation and the dependent variable $\mathrm{Cl}$ - Competencies innovation, is somewhat alarming, since it shows that even if organizational value innovation is perceived to be important within the organization, managers do not seem to show it through 
their work so directly. Nevertheless, innovation is important for every organization since it is the source of prosperity. There was also statistically significant correlation $(r=0.534)$ as well as moderate level of variability $(28.3 \%)$ explained between the independent variable OVR - Organizational value responsibility and dependent variable $C R$ - Competencies responsibility. This was somewhat expected, since responsible behavior is promoted by all societies. Results also show that responsibility as a value positively influences responsible behavior of managers. The statistically significant correlation $(r=0.397)$ as well as the moderate level of variability $(15.5 \%)$ explained between independent variable OVE - Organizational value ethics and dependent variable $C E$ - Competencies ethics, was also somewhat expected, since ethical behavior has been promoted by all the levels in society for decades. Results also show that ethics as a value influences managers' ethical behavior and is reflected in their work practice. The statistically significant correlation $(r=0.523)$ as well as the level of variability $(27.2 \%)$ explained between independent variable OVC Organizational value costumers and dependent variable CC - Competencies costumers, indicates the importance of customers. This result, as may be argued by some, might be viewed as overstated, given that research was done in a sector that is focused on direct customers (travel and leisure). However, research questions did not distinguish between different types of customers. Nevertheless, results support the initial claim that customers as an organizational value influence the behavior focused on customer satisfaction by managers. Finally, there is statistically significant correlation $(r=0.497)$ as well as a relatively high level of variability $(24.5 \%)$ explained between the independent variable OVEm - Organizational value employees and the dependent variable CEm - Competencies employees, what was also somewhat expected, given that cooperation with employees promotes the idea discussed in Management by values theory (MBV) that employees must be valued. The results clearly show that employees as a value influence managers' behavior, which is focused on cooperation with employees.

Our research had certain limitations. First, there was the research instrument, i.e. the questionnaire. On the one hand, it is the most appropriate tool for research, but on the other hand, structured questionnaires give little room for in-depth knowledge on certain subjects. Second, there is the limitation of the sample. We decided to conduct a research in a single sector. Ideally the research would be undertaken on a larger scale, including several sectors. However, the validity of the research [27] made in a single sector and concluded that results can indeed be generalized if the selected sector is not specifically denoted by population assumptions. Another limitation to this research also lies in the fact that it was conducted in a single country, hence, results may vary by country. Overall, we believe that results are still representative and the limitations are withheld to the minimum, thus results are generally applicable and can also be used for further research.

From the viewpoint of practice the results clearly support the theoretical conceptualizations [17] that in the 21st century is most likely to bring about changes in everyday work life that will impact the ways, in which organizations are managed. We believe that organizational values are very important for organizational performance. Hence, they are not just a marketing tool for customer aquisition. Organizational values are becoming increasingly important, and are having an influence on managers' behavior and their work practice. However these results should not give the reader the assumption that only those organizations with healthy organizational values, which are incorporated into managers' competencies, will be able to prosper in the future, there is no doubt that these organizations will be more successful but setting goals is still very much important, and values as well as competencies will just be a tool that will help set proper goals and show proper paths to reach them.

\section{References}

[1] ABU-BADER, SOLEMAN HASSAN. Using statistical methods in social science research with a complete spss guide. Chicago: Lyceum Books Inc., 2011. ISBN 978-1-935871-02-6.

[2] ALAS, R., ENNULO, J., TÚRNPUU, L. Managerial Values in the Institutional Conetct. Journal of Business Ethics. 2006, Vol. 65, Iss. 3, pp. 269-278. ISSN 0167-4544. doi:http://dx.doi. org/10.1007/s10551-005-5494-1.

[3] ALLPORT, G. W. Pattern and growth in personality. New York: Holt, Rinehart and Willson, 1961. ISBN 0-03-010810-1. 
[4] ARAGON, S. R., JOHNSON, S. D. Emerging roles and competencies for training in e-learning environments. Advances in Developing Human Resources. 2002, Vol. 4, Iss. 4, pp. 424-439. ISSN 1523-4223. doi:http:// dx.doi.org/10.1177/152342202237520.

[5] BERSON, Y., SHAUL, O., TALY, D. CEO values, organizational culture and firm outcomes. Journal of Organizational Behaviour. 2008, Vol. 29, pp. 615-633. ISSN 0894-3796. http://dx.doi.org/10.1002/job.499.

[6] BLANCHARD, K., O`CONNOR, S. Managing by Values. San Francisco: Berrett-Koehler Publishers, 1996. ISBN 1576750078.

[7] BOHLANDER, G., SNELL, S. Managing Human Resources. 13th ed. Manson: Thomson South-Western, 2004. ISBN 978-0324184051.

[8] BOON, J., VAN DER KLINK, M. (Ed.). Competencies: the triumph of a fuzzy concept. In: Academy of Human Resource Development Annual Conference. Honolulu: Proceedings. 2002, Vol. 1, pp. 327-334. ISSN 1532-1096.

[9] BOYATZIS, E. R. The competent manager. New York: John Wiley, 1982. ISBN 9780471090311.

[10] BRATTON, J., GOLD, J. Human Resources Management: Theory and practice. 3rd ed. New York: Palgrave Macmillan, 2003. ISBN 9780333993262.

[11] BRUKE, J. R. Managerial feedback, organizational values and service quality. Managing Service Quality. 1999, Vol. 9, Iss. 1, pp. 53-57. ISSN 0960-4529. doi:http://dx.doi. org/10.1108/09604529910248812.

[12] CAMISÓN, C., MONFORT-MIR, V. M. Measuring innovation in tourism from the Schumpeterian and the dynamics-capabilities perspectives. Tourism Management. 2012, Vol. 33, Iss. 4, pp.776-789. ISSN 0261-5177.doi:http:// dx.doi.org/10.1016/j.tourman.2011.08.012.

[13] CAPPELLI, P., CROCKER-HEFTER, A. Distinctive human resources are firms' core competencies. Organisational Dynamics. 1996, Vol. 24, Iss. 3, pp. 6-22. ISSN 00902616. doi:http://dx.doi.org/10.1016/S00902616(96)90002-9.

[14] CHATMAN, J. A., CHA, S. Leading by Leveraging Culture. California Management Review. 2003, Vol. 45, Iss. 4. ISSN 2162-8564. doi:http://dx.doi.org/10.2307/41166186.

[15] CPI. Poklicni standard Manager/Managerka $v$ manjšem hotelu [online]. 2008 [cit. 2011-0210]. Available from: http://www.nrpslo.org/ris/ preview.aspx/81100120.
[16] COLLINS, J. C., PORRAS, J. I. Built to last: successful habits of visionary companies. London: Random House, 2002. ISBN 1-55778723-9.

[17] DOLAN, S. L., GARCIA, S. Managing by values: Cultural redesign for strategic organizational change at the dawn of the twenty-first century. Journal of Management Development. 2002, Vol. 21, Iss. 2, pp. 101117. ISSN 0262-1711. doi:http://dx.doi. org/10.1108/02621710210417411.

[18] DOLAN, L. S., GARCIA, S., RICHLEY, B. Managing by Values: A Corporate Guide to Living, Being Alive, and Making a Living in the 21st Century. London: Palgrave Macmillan, 2006. ISBN 0-230-00026-6.

[19] DRUCKER, P. F. The Practice of Management. New York: Harper \& Row, 1954. ISBN 0060110953.

[20] EDMONDSON, A. C., CHA, S. E. When Company Values Backfire. Harvard Business Review. 2002, Vol. 80, Iss. 11, pp. 18-19. ISSN 0017-8012. doi:10.1016/j.leaqua.2005.10.006.

[21] ENGLAND, G. W. Personal Value Systems of American Managers. Academy of Management Journual. 1967, Vol. 10, Iss. 1, pp. 53-68. ISSN 0001-4273. doi:http://dx.doi. org/10.2307/255244.

[22] FERLIGOJ, A., LESKOVŠEK, A., KOGOVŠEK, T. Veljavnost in zanesljivost merjenja. Ljubljana: Fakulteta za družbene vede, 1995. ISBN 86-80227-47-1.

[23] FOSS, N. J., KNUDSEN, C. Towards a Competence Theory of the Firm. London: Routledge, 1996. ISBN 0415407028.

[24] GORENAK, M. Model povezanosti organizacijskih vrednot in kompetenc vodji $v$ gostinsko nastanitveni dejavnosti / A model of influence of organizational values on managres' competencies in hotel industry sector. Doctoral thesis. 2013.

[25] GROVES, K. S., LAROCCA, M. A. Responsible Leadership Outcomes Via Stakeholder CRS Values: Testing a VaulesCentered Model of Transformational Leadership. Journal of Business Ethics. 2011, Vol. 98, pp. 37-55. ISSN 0167-4544. doi:http://dx.doi. org/10.1007/s10551-011-1019-2.

[26] GUZZO, R., SALAS, E. (Eds.). Team effectiveness and decision making in organizations. San Francisco: Jossey-Bass, 1995. ISBN 978-1-55542-641-5.

[27] HANNAN, M. T., FREEMAN, J. The Population Ecology of Organizations. The 
American Journal of Sociology. 1977, Vol. 82, Iss. 5, pp. 929-964. ISSN 0002-9602. doi:http:// dx.doi.org/10.1086/226424.

[28] HARTLE, F. How to Re-engineer your Performance Management Process. London: Kogan Page, 1995. ISBN 0749416408.

[29] HOERR, J. The payoff from teamwork. Business Week. 1989, Iss. $10^{\text {th }}$ July, pp. 56-62. ISSN 0007-7135.

[30] HOFSTEDE, G. Attitudes, Values, and Organizational Culture: Disentangling the Concepts. Organization Studies. 1998, Vol. 19, Iss. 3, pp. 477-492. ISSN 0170-8406. doi:http:// dx.doi.org/10.1177/017084069801900305.

[31] HOLLAND, J. L. The vocational preference inventory. Palo Alto, CA: Consulting Psychologists Press, 1977. ISBN 978-1412905374.

[32] HOLLAND, J. L. Making Vocational Choices: A theory of Vocational Personalities and Work Enviroments. 2nd ed. New York: Prentice Hall, 1985. ISBN 0911907270.

[33] JIN, G. K., DORZDENKO, R. G. Relationships among percived organizational core values, corporate social responsibility, ethics and organizational performance outcomes: An empirical study of information technology profesionals. Journal of Business Ethics. 2010, Vol. 92, pp. 341-359. ISSN 0167-4544. doi:http:// dx.doi.org/10.1007/s10551-009-0158-1.

[34] JUDGE, T. A., CABLE D. M. Applicant Personality, Organizational Culture, and Organizational Attraction. Personnel Psychology. 1997, Iss. Summer, pp.359-394. ISSN 1744-6570. doi:http://dx.doi.org/10.1111/j.1744-6570.1997. tb00912.x.

[35] KENNY, T. From vision to reality through values. Management development review. 1994, Vol.7,Iss.3, pp.17-20.ISSN0962-2519.doi:http:// dx.doi.org/10.1108/09622519410060375.

[36] KLENKE, K. Corporate values as a multi-level, multi-domain antecendents of leader behavoiur. International Journal of Manpower. 2005, Vol. 26, Iss. 1, pp. 50-66. ISSN 0143-7720. doi:http:// dx.doi.org/10.1108/01437720510587271.

[37] KOHONT, A. Kompetenčni profil slovenskih strokovnjakov za upravljanje človeških virov. Master thesis. 2005. Ljubljana: Fakulteta za družbene vede.

[38] KOŠMELJ, B., ROVAN, J. Statistično sklepanje. Ljubljana: Ekonomska fakulteta univerze v Ljubljani, 1997. ISBN 961-6081-70-5. [39] KOZLOWSKI, S. W., DOHERTY, M. Integration of climate and leadership: examination of a neglected issue. Journal of applied psychology. 1989, Vol. 74, Iss. 4, pp. 546-553. ISSN 0021-9010. doi:http://dx.doi. org/10.1037/0021-9010.74.4.546.

[40] LEWIN, K. Field theory in social science. New York: Harper \& Row, 1951. ISBN 1557984158.

[41] MANGHAM, I. In search of competence. Journal of General Management. 1986, Vol. 12, Iss. 2, pp. 5-12. ISSN 0306-3070.

[42] MCCLELLAND, D. Identifying competencies with behavioural-event interviews. Psychological Science. 1998, Vol. 9, Iss. 5, pp. 331-339. ISSN 0956-7976. doi:http://dx.doi.org/10.1111/14679280.00065 .

[43] MILFELNER, B., SNOJ, B., PISNIK KORDA, A. Measurment of precived quality, precived value, image and satisfaction interrelations of hotel services: Comparison of tourists from Slovenia and Italy. Društvena Istraživanja. 2011, Vol. 3, Iss. 20, pp. 605-624. ISSN 1330-0288. doi:http://dx.doi.org/10.5559/di.20.3.01.

[44] MUSEK, L. K. Vrednote poslanstvo in vizija podjetja. Koper: Fakulteta za menedžment, 2008. ISBN 978-961-266-011-6.

[45] NEW, G. A three-tier model of organizational competence. Journal of Managerial Psychology. 1996, Vol. 11, Iss. 5, pp. 44-51. ISSN 0268-3946. doi:http://dx.doi. org/10.1108/02683949610150051.

[46] PERRENOUD, P. The Key to Social Fields: Essay on the Competencies of an Autonomous Actor, A Sociological Perspective. DeSeCo Expert Report. Neuchâtel: Swiss Federal Statistical Office, 1999. ISBN 3-303-15297-7.

[47] PETERS, T. J., WATERMAN, R. H. In search of excellence: lessons from America's best run companies. New York: Warner, 1982. ISBN 978-0446385077.

[48] PFIEFFER, W. J., GOODSTEIN, L. D., NOLAN, T. M. Understanding applied strategic planning:A manager's guide.San Diego:University Associates Inc., 1985. ISBN 0883901838.

[49] POSNER, B. Z., KOUZES, J. M., SCHMID, W. H. Shared values make a difference: An empirical test of corporate culture. Human Resource Management. 1985, Vol. 24, Iss. 3, pp. 293-309. ISSN 0090-4848. doi:http://dx.doi. org/10.1002/hrm.3930240305.

[50] ROKEACH, M. Beliefs, Attitudes and Values. San Francisco: Jossey-Bass Inc., 1968. ISBN 087589013X.

[51] ROKEACH, M. The nature of human values. New York: The Free Press, 1973. ISBN 978-0029267509. 


\section{Ekonomika a management}

[52] SCHEIN, E. H. Organizational Culture and Leadership: A Dynamic View. San Francisco: Jossey-Publisher, 1987. ISBN 978-1555423315. [53] SCHWARTZ, S. H. Universals in the contetn and structure of values: Theoretical advances and empirical tests in 20 countries. Advances in experimental social psychology. 1992, Vol. 25, pp. 1-65. ISSN 0065-2601. doi:http://dx.doi. org/10.1016/S0065-2601(08)60281-6.

[54] SCHWARTZ, S., BILSKY, W. H. Toward a universal psychological structure of human values. Journal of Personality and Social Psychology. 1987, Vol. 53, Iss. 3, pp. 550562. ISSN 0022-3514. doi:http://dx.doi. org/10.1037/0022-3514.53.3.550.

[55] SIMMERLY, R. G. Strategic planing and leadership in continuing education. San
Francisco: Jossey-Bass Publishers, 1987. ISBN 978-1555420345.

[56] THOMPSON, J., RICHARDSON, B. Strategic competency: The learning challange. Journal of Workplace Learing. 1996, Vol. 9, Iss. 5, pp. 153-162. ISSN 1366-5626.

assist. prof. Mitja Gorenak, Ph.D. University of Maribor Faculty of Tourism mitja.gorenak@um.si

prof. Marko Ferjan, Ph.D. University of Maribor Faculty of Organizational Sciences marko.ferjan@fov.uni-mb.si 


\section{THE INFLUENCE OF ORGANIZATIONAL VALUES ON COMPETENCIES OF MANAGERS}

\section{Mitja Gorenak, Marko Ferjan}

This paper discusses the influence of organizational values on managers' competencies. Organizational values are a reflection of individual values of founder or founding members of the organization. Through time organizational values are shaped by every member of the organization and by events that shape the organization. On the other hand competencies of managers are not shared by the whole organization though they do influence the way managers run their organizations and through this also how organizations work. Based on the findings of previous studies a model for measuring the influence of organizational values on managers' competencies was proposed. More specifically, by conducting a preliminary study a model was created that discusses the influence of six most commonly stated organizational values on the matching competencies. To this end research question has been proposed: What is the level of correlation between organizational values and matching competencies of managers? The paper-and-pencil survey was carried out in the travel and leisure industry, where 1,100 employees were surveyed. The 388 participants who filled out the questionnaire represent a $35.27 \%$ yield of surveys sent out and $4.26 \%$ of the population of this industry in Slovenia. We have determined that there is a statistically significant influence of organizational values on matching competencies. This finding clearly indicates that organizational values have a strong influence on managers' competencies. This also to some extent supports the idea of managing by values where managing of organizations is focused on organizational values and every decision is done through the scope of these values.

Key Words: Values, organizational values, competencies, model, travel and leisure industry.

JEL Classification: M12.

DOI: 10.15240/tul/001/2015-1-006 